\title{
Requirements for applying the concept of social entrepreneurship in the branch of Taibah University in the Khyber Governorate A field study
}

\author{
Abdallah Abdallah Ahmed El-Tabbal \\ Department of Business Administration \\ Faculty of Commerce, Suez University, Egypt
}

\section{Keywords}

Social entrepreneurship, Initiative ,innovation, acceptance of risk, voluntary participation, application of the concept of entrepreneurship.

\begin{abstract}
This study aimed to investigate the availability of the requirements for applying the concept of social entrepreneurship in the branch of Taibah University in the Khyber region in Saudi Arabia. To achieve this aim of the study, three basic hypotheses were formulated and tested using preliminary data collected through the survey, Data was collected by a convenience sample, the sample of study consisted of (307) students and faculty members, Data analysis and hypothesis testing have been depended on use methods of a structural equation modelling, path analysis, and direct and indirect analysis by using the Bootstrap method, The study found a significant effect of the dimensions of social entrepreneurship in the application of the concept of social entrepreneurship in Taibah University branch, And the relative importance of the requirements for applying the concept of social entrepreneurship, it's arranged as follows: (innovation - voluntary participation acceptance of risk - Initiative) ,The importance of the requirements for applying the concept of social entrepreneurship in the branch of Taibah University varies according to gender, specialization and function with regard to the dimensions of (acceptance of risk and voluntary participation) while it does not differ with regard to the dimensions of Initiative and innovation.
\end{abstract}

Corresponding author: Abdallah Abdallah Ahmed El-Tabal

Email addresses for the corresponding author: altabal2000@yahoo.com

First submission received: $20^{\text {th }}$ April 2020

Revised submission received: $12^{\text {th }}$ May 2020

Accepted: 29th May 2020

\section{Introduction}

Entrepreneurship has become one of the important topics that is presented in the current on the local and international scene due to its effective role in the economies of countries, and it is considered one of the most important growth engines through the establishment of effective organizations that to contribute of development by reducing unemployment, employing young people and increasing revenue (Zina and Al-Habib, 2014). The concept of social entrepreneurship is not considered a modern concept as some belief, but it has appeared in the past under many names and has witnessed a remarkable development since its emerged as a method that has a positive social or environmental impact, and the development of new management practices that take into account the social and environmental aspects and every job in the organization focuses on social impact more From increasing profit, such as green and environmentally friendly energy projects and providing job opportunities for youth (Abdo, Fahmy, Greenwald, and Nelson, 2010).

Social entrepreneurship as a new mechanism aims to maximize optimization and create social value, and represents a continuous challenge to the survival of organizations in the markets, and contributes to community development and the provision of services to citizens, in addition to attention to human development and social or environmental issues in the long term, such as poverty, and unemployment (offer, 2006). This concept is expected to spread in the coming years to confront social or environmental issues such as clean and alternative energy, women's empowerment, education, health, etc., and achieving social welfare for future generations (Mari and Marti, 2006). Dees (2007) emphasize 
that there is a necessary need to establish, Organizing social projects. Dees (2001); Dees, Anderson and Wei-Skillern (2004); Austin, Stevenson and Wei-Skillern (2006) addressed Social entrepreneurship as a phenomenon and as an initiative.

The present study attempts to identify the requirements for applying the concept of social entrepreneurship and its most important dimensions in the branch of Taibah University in the Khyber Governorate, Saudi Arabia. So, this study attempts to answer the following research question, what are the requirements for applying the concept of social entrepreneurship in the branch of Taibah University in the Khyber Governorate?

\section{Literature review}

\subsection{Concept of social entrepreneurship}

The concept of social entrepreneurship is a relatively new concept and a new field of research (Dacin, P., Dacin, M. and Matear, 2010), the process of studying social entrepreneurship is a multidimensional and complex phenomenon that differs at the individual, organizational and group level (Mari and Marti, 2004; Wee-liang and Teck-Meng, 2005), therefore there is no agreement yet between writers and researchers on the existence of a common and agreed definition of it (Bornstein and Davis, 2010; Hartigan, 2006).so There is a difference between researchers in their view of this concept as follows: Sagawa and Segal (2000) consider it a practice of social responsibility for business in the common sectors. Alvord, Brown, and Letts (2004) refer to it as finding solutions to social problems and creating new ideas, capabilities, resources, and organizations to support the process of social transformation. While Austin, et al. (2006) see it as non-profit initiatives and strategies to create value or social benefit. Mort, Weerawardena and Carnegie (2003) define it as a multi-dimensional concept that includes many behaviours of entrepreneurship to achieve the social mission, cohesion and unity of purpose, behaviour, implementation, facing complexity, creating opportunities and social benefit. Robinson (2006) define it as containing social investment and social enterprise in for-profit and not-for-profit organizations with the aim of achieving an environmental or social impact, and hence financial returns. Mari and Marti (2006) see it as a process that includes: creating social added value by collecting resources in a new way, new ways of working, managing creativity, social innovation, creative demolition, exploring and exploiting opportunities, satisfying changing social needs, providing products and services by creating new projects, Social entrepreneurship, social self-entrepreneurship, acceptance of risk, and social change.

According to Helm (2007) define it as a process that represents the spirit of initiative in social organizations to generate social benefit, facilitate social change in society and the social or industrial sector through the use of a mixture of innovation, risk, initiative, a discover and exploit new opportunities to create a positive social impact. And Adetu (2014) sees it as a method to treatment problems social and environmental by integrating innovation and opportunity in a pioneering way, thus generating revenue from the process of social transformation.

\subsection{The requirements for applying the concept of social entrepreneurship}

The results of a study (Dees, 2002) indicate that to ensure the survival and success of social organizations in the market at present requires the following requirements: achieving initiative at work, building and management skills, and organizing social projects through practical and applied training programs, and social participation. While the results of the (Weerawardena and Mort, 2006) study indicates that the concept of social entrepreneurship is multidimensional and includes the following application requirements and dimensions to maximize social benefit: innovation, initiative, risk management, and that there is increase a spread the importance of this concept in recent years. (Abdo et al. 2010) also indicates that there is a possibility for growth and spread of the application of the concept of social entrepreneurship in the Arab countries as result: an increase in the proportion of voluntary work, interest in private work, decrease in dependence on government work to achieve freedom, independence at work, and increased participation in new and innovative projects useful to society. The results of the study (Luke and Chu, 2013) reveal that social entrepreneurship is a creative and unique non-profit initiative, and it is a best practice for managing social projects and achieving change, social transformation, and acceptance of risks. 
While the results of the study (Haider, 2014) indicate that there is a relationship between youth initiatives and social leadership in Jordanian civil society organizations, and among the most important of these initiatives are: social initiatives, community service, and voluntary work initiatives. Helm (2007) believes that social entrepreneurship is a unique and creative initiative, not-for-profit, and is one of the best management practices for managing social projects and achieving high performance by combining the dimensions of innovation, risk, and initiative. According to study (Jiao, 2011) found a relationship between social entrepreneurship, human and social capital, and decision-making process considering a set of environmental and institutional factors and contributes positively to achieving a positive social impact. And the Social Investment Report of Shell International in the Sultanate of Oman (2011) indicates that social investment contributes positively to achieving social goals and giving them social value, and this positively affects the company's performance, by focusing on four areas called 3E's rule and RS, it: recruitment, development, creativity and innovation, promoting, supporting and promoting entrepreneurship, environmental management practices, reducing road accidents.

The results of the study (Al-Wafi, 2012) indicates Nokia's achievement of environmental or community leadership through its achievement of initiative and excellence in the field of friendship with the environment, maximizing the positive impacts of its environmental and social aspects, achieving leadership in the field of its environmental performance, and applying environmental management systems. While a study (El-Ebrashi, 2013) indicates that social entrepreneurship contributes positively to achieving a positive social impact through three factors: personal, social, or behavioural factors, and attitude. Study (Sullivan, Weerawardena and Carnegie, 2003) developed a conceptual framework for applying social entrepreneurship in non-profit social organizations, consisting of six components: social mission, the balance of judgments, an exploration and exploitation of opportunities to find value for clients, innovation, initiative, and risk. Kavanagh, Murphy, and Dwyer (2012) believe that a culture of free and entrepreneurial social work can be developed among youth by teaching initiative, independence, risk-taking and learning from mistakes or failures.

We conclude from the previous presentation that the requirements for applying the concept of social entrepreneurship in this study include: (initiative - innovation - acceptance of risk - voluntary participation) (see Figure 1). Therefore, in this study, it is hypothesized that:

H1: There is a statistically significant effect of the dimensions of social entrepreneurship under study: (initiative - innovation - acceptance of risk - voluntary participation) in applying the concept of social entrepreneurship in the branch of Taibah University in the Khyber Governorate.

H2: varies the relative importance of the requirements for applying the concept of social entrepreneurship under study: (initiative - innovation - acceptance of risk - voluntary participation) in the branch of Taibah University in the Khyber Governorate.

H3: The importance of the requirements of applying the concept of social entrepreneurship (initiative innovation - acceptance of risk - voluntary participation) in the branch of Taibah University in the Khyber Governorate varies according to gender, specialization, and job.

\section{Research methodology}

\section{1 methodology}

This research uses structural equation modelling (SEM) to measure the variables of the study. Based on the descriptive analytical approach is used in its survey method, which depends on data collection, organization, and analysis through relying on theoretical and field study method to achieve the objectives of the research. Figure 1 illustrates The Proposed research framework. 
Figure (1) the proposed model for the study

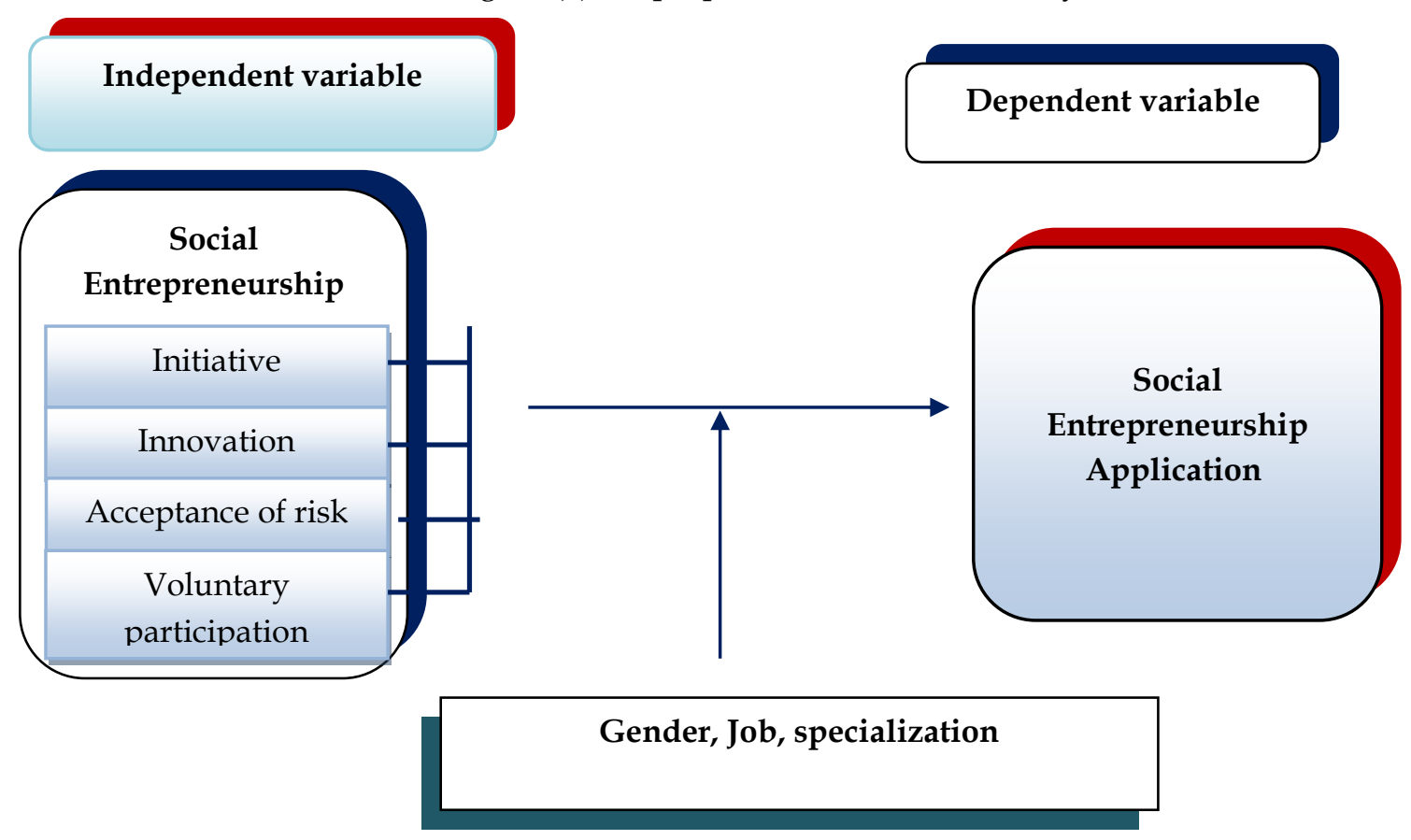

\subsubsection{Measuring variables}

First, a measurement model is designed to determine the significance of path coefficients (factor loadings) between multiple variables (observed variables) and (latent variables), It allows making sure the validity of the model. Next, a structural model is designed to verify the significance of statistical influences or regression weights, enabling testing of the causal relationships between the variables that were hypothesized in the proposed conceptual model.

\subsubsection{The questionnaire design and data collection}

A Questionnaire was designed to collect primary data from the different research categories, and the survey list includes a set of questions about the dimensions and requirements of applying the concept of social entrepreneurship under study (independent and dependent variables) based on a scale (Justin, 2012; Helm, 2007), with making some required adjustments On phrases to match the objectives of the current study. As well as an open question about the proposals of research groups regarding the extent to which the requirements of applying the concept of social entrepreneurship understudy contribute to the success of its application in the university branch, and a set of questions related to general data to identify the characteristics of the research sample. The five-point Likert scale was used. A questionnaire was used to collect data, is divided into three parts, the first part: demographic data (age, gender, level of education, job). The second part deals with information about the dimensions of social entrepreneurship (initiative innovation - acceptance of risk - voluntary participation) under study (independent variables), the third part deals with information about the applying concept of social entrepreneurship.

\subsubsection{Research population and Sampling}

The research population is represented in the students of the Taibah University branch in the Khyber Governorate in the Kingdom of Saudi Arabia to research the extent of their attitudes towards the requirements of applying the concept of social entrepreneurship at the university, and their number reached (1554) students during the second semester 1438/1439 H, and it is clear the heterogeneity of the research community vocabulary according to the speciality And gender, and a stratified random sample was withdrawn, its total size according to the sample size determination tables (322) single (Sekaran,2003), and the number of valid lists reached 277 lists, and the rate of correct responses reached \%86,02, which is a high and acceptable rate for scientific research purposes, In addition to 30 lists for faculty members. 


\section{Data analysis}

\subsection{Measurement model}

The researcher used The Social Sciences Statistical Package (SPSS / PC +, v. 22), (AMOS, v. 22), Use the SEM model equations to test the suitability or conformity of the model to the data. The following statistical methods due to their compatibility with the nature of the study data:

The Alpha Cronbach's Reliability Coefficient to assess the reliability of the set of phrases that measure study variables, the Confirmatory Factor Analysis (CFA) to verify structural validity of the scale, exploratory factor analysis (EFA) to test the validity and veracity of study variables , Composite Reliability (CR), and Average Variance Extracted (AVE), (see table 1). Path analysis and determination of Critical Ratio for Regression Weight to test the hypotheses of the study and verify the existence of a significant relationship between the dimensions of the independent and dependent variable. Standardized Direct Effect, Standard Indirect and Mediation testing using the bootstrap method to determine direct and indirect impact relationships between independent, dependent, and intermediate variables.

Table (1) exploratory factor analysis, Confirmed Factor Analysis, Composite Reliability, Cronbach's Alpha Average Variance Extracted

\begin{tabular}{|l|l|l|l|l|l|}
\hline & EFA & CFA & CR & $\begin{array}{l}\text { Cronbach's } \\
\text { alpha }\end{array}$ & AVE \\
\hline Initiative1 & .79 & .79 & & & \\
\hline Initiative2 & .77 & .78 & & & \\
\hline initiative 3 & .80 & .83 & & & \\
\hline initiative 4 & .87 & .96 & & & \\
\hline initiative & & & 83. & & .64 \\
\hline Innovation1 & .81 & .78 & & & \\
\hline Innovation2 & .81 & .79 & & & \\
\hline Innovation3 & .82 & .79 & & & \\
\hline Innovation4 & .79 & .74 & & & \\
\hline Innovation & & & 83. & .82 & .67 \\
\hline Risk1 & .85 & .83 & & & \\
\hline Risk2 & .86 & .83 & & & \\
\hline Risk3 & .84 & .81 & & & \\
\hline Risk4 & .83 & .78 & & & \\
\hline Risk & & & .87 & .86 & .70 \\
\hline Participate1 & .80 & .76 & & & \\
\hline Participate2 & .82 & .79 & & & \\
\hline Participate 3 & .76 & .70 & & & \\
\hline Participate 4 & .86 & .84 & & & \\
\hline Participate5 & .81 & .95 & & & \\
\hline Participate & & & .90 & .89 & .68 \\
\hline Classi1 & .75 & .74 & & & \\
\hline Classi2 & .75 & .72 & & & \\
\hline Classi3 & .72 & .79 & & & \\
\hline classification & & & 76. & .75 & \\
\hline Application1 & .70 & .68 & & & \\
\hline Application2 & .71 & .68 & & & \\
\hline Application3 & .69 & .66 & & & \\
\hline Application4 & .68 & .63 & & & \\
\hline Application & & & .72 & .71 & \\
\hline
\end{tabular}

It is clear from the previous table that the values of the alpha coefficient range between $(71 \%$, $89 \%)$, the values of confirmatory factor analysis are between $(63 \%, 95 \%)$, Composite Reliability values are between $(72 \%, 90 \%)$, and the values of the Average Variance Extracted Between $(55 \%, 70 \%)$, exploratory factor Analysis between $(68 \%, 87 \%)$, This means an acceptable increase in the reliability of each variable, where all values exceed $50 \%$ and the height of the dependency coefficients reflects the high degree of 
internal consistency and honesty between the contents of each of the previous variables, and also means the ability to rely on these variables in practice, and the validity of the model to measure variables studying. The survey is accepted if the Alpha Cronbach's coefficient or persistence ratio is greater than 60\% (Sekaran, 2003; Mcclave, Benson and Sincich, 2001).

\section{Testing of hypotheses}

Figure (2) path analysis of the proposed structural equations model for the study variables

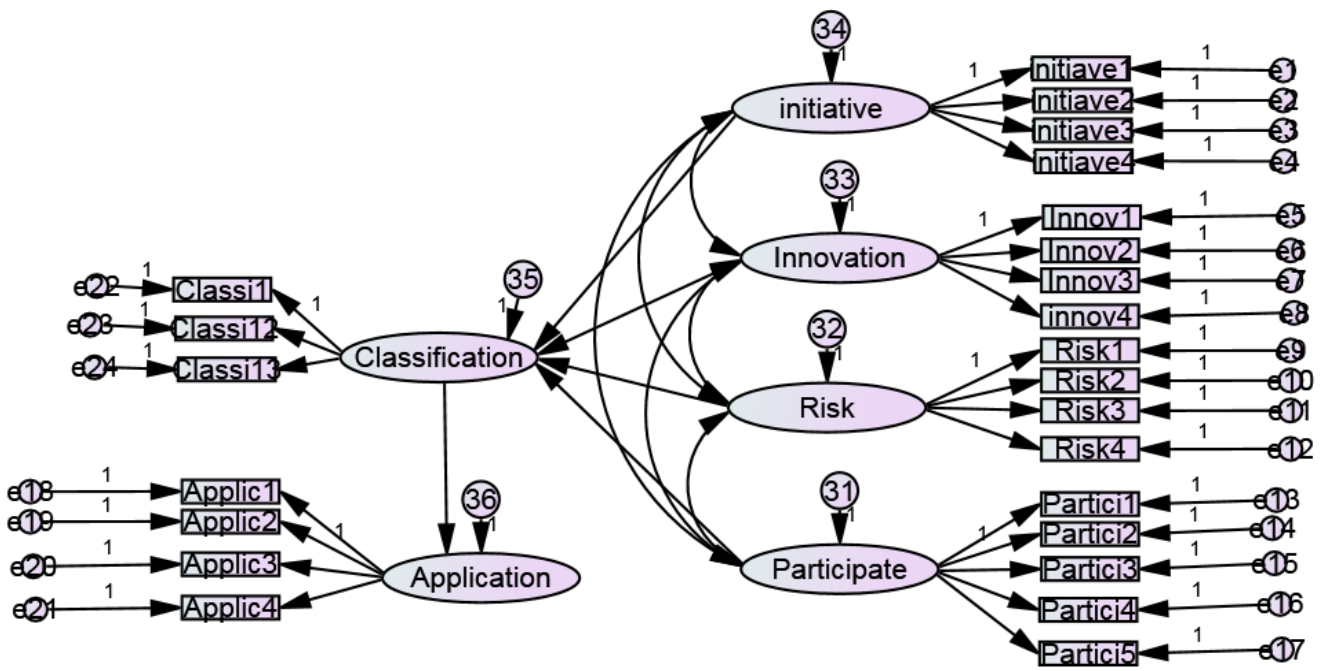

Table (2) Conformity quality indicators for the proposed SEM structural model for the study (Model fit)

\begin{tabular}{|l|l|l|}
\hline Measures & Fit Indices & Threshold Values \\
\hline CMIN/DF & 1.5 & Less than 3 \\
\hline GFI & 0.99 & 0.90 and above \\
\hline AGFI & 0.97 & 0.90 and above \\
\hline CFI & 0.98 & 0.90 and above \\
\hline TLI & 0.96 & 0.90 and above \\
\hline NFI & 0.96 & 0.90 and above \\
\hline RMSEA & 0.03 & Less than 0.08 \\
\hline
\end{tabular}

It is clear from the previous table that all the values of indicators of conformity or suitability of the model are high and exceed the ideal limits, which means acceptance and validity of the model to measure the relationship between the study variables. To test the study hypotheses and verify that there is a significant relationship between the dimensions of the dependent and independent variable, the following table displays a summary of the results of the regression coefficients between the study variables:

Table (3) Regression Weights: (Group number 1 - Default model)

\begin{tabular}{|lll|lllll|}
\hline & & & Estimate & S.E. & C.R. & P & Label \\
\hline initiative & $<---$ & Application & .842 & .151 & 5.567 & $* * *$ & \\
Innovation & $<---$ & Application & 1.245 & .178 & 6.981 & $* * *$ & \\
Risk & $<---$ & Application & 1.025 & .155 & 6.609 & $* * *$ & \\
Participate & $<---$ & Application & 1.094 & .165 & 6.632 & $* * *$ & \\
\hline
\end{tabular}

It is clear from the previous table that the proposed model of the study included good values for indicators, and this is shown by the table of indicators of conformity quality, and all estimates of the model are significant at the level of significance 0.05 . The calculated value is greater than the tabular value of $C R \pm 1.96$, and values this indicates that the expressions for each dimension are able to measure and 
accept the values of the structural validity coefficients for the scale, and therefore can be relied upon to estimate the relationship between the independent variable and the dependent variable.

Through the results shown in the previous table, the following hypothesis can be tested as follows:

The hypothesis $(\mathrm{H} 1 / 1)$ was accepted, a value of $\mathrm{CR}=5.567$ (i.e. more than \pm 1 . 96) that indicate to the effect of an independent variable on the dependent variable is significant, and (Estimate $=.842$ ) with a positive sign indicating that there is a positive relationship between Entrepreneurial spirit and applying the concept of social entrepreneurship, and significant, the value of $P=.000$ (i.e. less than 0.05 ) This indicates the relationship is significant.

The hypothesis $(\mathrm{H} 1 / 2)$ was accepted, a value of $\mathrm{CR}=6.981$ (i.e. more than \pm 1 . 96) that indicate to the effect of an independent variable on the dependent variable is significant, and (Estimate $=1.245$ ) with a positive sign indicating that there is a positive relationship between innovation and applying the concept of social entrepreneurship, and significant, the value of $\mathrm{P}=.000$ (i.e. less than 0.05 ) This indicates the relationship is significant.

The hypothesis $(\mathrm{H} 1 / 3)$ was accepted, a value of $\mathrm{CR}=6.609$ (i.e. more than \pm 1 . 96) that indicate to the effect of an independent variable on the dependent variable is significant, and (Estimate $=1.025$ ) with a positive sign indicating that there is a positive relationship between acceptance of risk and applying the concept of social entrepreneurship, and significant, the value of $\mathrm{P}=.000$ (i.e. less than 0.05 ) This indicates the relationship is significant.

The hypothesis $(\mathrm{H} 1 / 4)$ was accepted, a value of $\mathrm{CR}=6.632$ (i.e. more than \pm 1 . 96) that indicate to the effect of an independent variable on the dependent variable is significant, and (Estimate $=1.094$ ) with a positive sign indicating that there is a positive relationship between voluntary participation and applying the concept of social entrepreneurship, and significant, the value of $P=.000$ (i.e. less than 0.05 ) This indicates the relationship is significant.

The most influential the dimensions of social entrepreneurship in applying the concept of social entrepreneurship in this study are innovation, followed by voluntary participation, then acceptance of risk, and finally initiative.

As a result of proving the validity of the hypotheses, the main hypothesis is validated, which states that there is a significant influence relationship between the dimensions of social entrepreneurship and applying the concept of social entrepreneurship. Thus, the first main hypothesis H1 is fulfilled, there is a statistically significant effect relationship of the social entrepreneurship dimensions on applying the concept of social entrepreneurship.

The hypothesis H2: was accepted, It is clear from the proof of the first hypothesis that the most influential dimensions social entrepreneurship in applying the concept of social entrepreneurship are: innovation, followed by voluntary participation, then acceptance of risk, and finally initiative.

Thus, the order of the independent variables in terms of their effect on the dependent variable is as follows: (innovation - voluntary participation - acceptance of risk - initiative). Then accept the second hypothesis.

The hypothesis H3: Standardized Direct Effect and Standardized Indirect Effect by Using the the bootstrap method, to test hypothesis H3, Mediator variable test through Bootstrap method, the following table shows that:

Table (4) Results of the direct, indirect, and total effects of the study variables

\begin{tabular}{|c|c|c|c|c|c|c|c|}
\hline \multicolumn{3}{|l|}{ Variables } & \multirow{2}{*}{$\begin{array}{l}\text { Direct path } \\
\text { coefficient } \\
\text { value }\end{array}$} & \multirow[t]{2}{*}{ Significant } & \multirow{2}{*}{$\begin{array}{l}\text { Indirect path } \\
\text { coefficient value }\end{array}$} & \multirow[t]{2}{*}{ significant } & \multirow{2}{*}{$\begin{array}{l}\text { Total path } \\
\text { coefficient } \\
\text { value }\end{array}$} \\
\hline Independent & Mediator & dependent & & & & & \\
\hline initiative & classification & Application & .445 & *** & .373 & *** & .818 \\
\hline Innovation & classification & Application & .641 & *** & .561 & 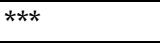 & 1.202 \\
\hline Risk & classification & Application & .221 & $* * *$ & .355 & *** & .576 \\
\hline Participate & classification & Application & .433 & $* * *$ & .541 & *** & .974 \\
\hline classification & - & Application & .346 & - & .000 & - & .346 \\
\hline
\end{tabular}

The previous table shows the following:

(A) The study included the following functional and personal variables (Intermediate variables): The sample is divided by gender: male (56.6\%), female (43.4\%). according to Job: (30) faculty www.jbrmr.com A Journal of the Centre for Business \& Economic Research (CBER) 
members, (277) students, and according to specialization: business administration (28.9\%), accounting (31.6\%), computers (20.6\%), other specialities (18.9\%).

(B) There is a direct and indirect a significant effect of the dimensions of social entrepreneurship (initiative and innovation) on the application of social entrepreneurship, and the value of the level of significance was less than (0.05).

(C) The direct impact of the dimensions of social entrepreneurship (initiative and innovation) on the application of social entrepreneurship is greater than the indirect effect, which indicates that the dimensions of social entrepreneurship (initiative and innovation) directly affect the application, and personal and functional variables do not affect this relationship and it does not play a mediating role in influencing the relationship between the dimensions of social entrepreneurship and the application of social entrepreneurship, and therefore the importance of the requirements for applying the concept of social entrepreneurship (initiative and innovation) in the branch of Taibah University in the Khyber Governorate does not differ according to the gender, Specialization and job, and then rejected the third hypothesis with respect to the dimensions of (initiative and innovation). Although students realize the importance of social entrepreneurship, it may be due to the nature of entrepreneurship as a free work characterized by creativity and initiative, the weakness of the individual initiative among youth and the lack of an environment that encourages creativity and initiative. Abu Qarn (2015) indicates that there is an average role for creativity and innovation about the Entrepreneurial orientation in the Islamic University, while their role is few in Al-Azhar University.

Thus, the hypothesis H3/1 was rejected, the importance of the requirements of applying the concept of social entrepreneurship (initiative - innovation)) in the branch of Taibah University in the Khyber Governorate varies according to gender, specialization, and job.

(D) There is a direct and indirect a significant effect of the dimensions of social entrepreneurship (risk acceptance and voluntary participation) on the application of social entrepreneurship, and the value of the level of significance was less than (0.05).

(E) The indirect impact of the dimensions of social entrepreneurship (acceptance of risk and voluntary participation) on the application of social entrepreneurship is greater than the direct impact, which indicates that personal and functional variables play a mediating role in influencing the relationship between the dimensions of social entrepreneurship (acceptance of risk and voluntary participation) Apply social entrepreneurship, and thus accept the third hypothesis regarding the impact of personal and functional variables on the relationship between the dimensions of social entrepreneurship (acceptance of risk and voluntary participation) and the application of social entrepreneurship. Students' interest in positive community and volunteer participation, acceptance of perceived risk and their search for job opportunities, wealth, and social independence. Al-Farra (2018) indicates that youth in the university have positive attitudes towards social work and voluntary participation. While Abu Qarn (2015) indicates that there is an average role for the calculated risk of the Entrepreneurial orientation in the Islamic University, while its role is minimal in Al-Azhar University.

Thus, the hypothesis H3/2 was accepted, the importance of the requirements of applying the concept of social entrepreneurship (acceptance of risk - voluntary participation) in the branch of Taibah University in the Khyber Governorate varies according to gender, specialization and job.

\section{Discussions}

This study has found that there is a positive relationship between social entrepreneurship dimensions and applying the concept of social entrepreneurship. The main contribution of the research is social entrepreneurship effects on applying the concept of social entrepreneurship, the relationship between social entrepreneurship and applying the concept of social entrepreneurship needs to increase applying the concept of social entrepreneurship to its importance and benefits for organizations and societies. The other contribution is that the study found that there is a statistically significant relationship between the social entrepreneurship dimensions and applying the concept of social entrepreneurship. The results of this study are consistent with the results of previous studies in this field, such as the study of Abdo et al. (2010) indicates that there is a possibility for growth and spread of the application of the 
concept of social entrepreneurship. The study Luke and Chu (2013) reveal that social entrepreneurship is a creative and unique non-profit initiative. The results of the study Haider (2014) indicate that there is a relationship between youth initiatives and social leadership. Jiao (2011) found a relationship between social entrepreneurship and human and social capital and the decision-making process. The results of the study El-Ebrashi (2013) indicate that social entrepreneurship contributes positively to achieving a positive social impact.

Another contribution is that the study found that there is the order of the independent variables or the dimensions of social entrepreneurship in terms of their effect on the dependent variables or the applying the concept of social entrepreneurship is as follows: (innovation - voluntary participation acceptance of risk - initiative).

The study also found that there is the importance of the requirements of applying the concept of social entrepreneurship varies according to gender, specialization and job. The first and second hypotheses were validated, while the third hypothesis was partially rejected.

\section{Conclusion}

This study provides additional evidence to the literature concerning the impact of social entrepreneurship dimensions on applying the concept of social entrepreneurship. This study contributes by highlighting some factors that have not been widely examined in literature such as : (initiative innovation - acceptance of risk - voluntary participation). Although this study has proved that social entrepreneurship dimensions effects on increased applying the concept of social entrepreneurship. the relationship between social entrepreneurship dimensions and applying the concept of social entrepreneurship. Abdo et al. (2010) indicates that there is a possibility for growth and spread of the application of the concept of social entrepreneurship as a result: an increase in the proportion of voluntary work, interest in private work and a decrease in dependence on government work to achieve freedom and independence at work, and increased participation in new and innovative projects. The results of the study Luke and Chu (2013) reveal that social entrepreneurship is a creative and unique non-profit initiative, and it is a best practice for managing social projects and achieving change, social transformation, and acceptance of risks. the study Haider (2014) indicate that there is a relationship between youth initiatives and social leadership and among the most important of these initiatives are: social initiatives, community service, and voluntary work initiative Jiao (2011) study found a relationship between social entrepreneurship and human and social capital and the decision making process in light of a set of environmental and institutional factors, and contributes positively to achieving a positive social impact.

\section{Managerial implications}

According to the results of this research, it is clear that in the branch of Taibah University in the Khyber Governorate, management attention should be given to the concept of social entrepreneurship, which is one of the modern topics and is a modern trend in the twenty-first century, especially with the increase in unemployment rates and the employment crisis among graduates at present and relationship between the dimensions of social entrepreneurship in this study in applying the concept of social entrepreneurship. the order of the independent variables in terms of their effect on the dependent variable is as follows: (innovation - voluntary participation - acceptance of risk - initiative). This study contributes to increasing the understanding of managers of the needs of term social entrepreneurship and managers are advised to focus on providing Application requirements to increase and applying the concept of social entrepreneurship, Where social entrepreneurship is the cornerstone that complements academic institutions, especially universities, for carrying out social studies that focus on the basic needs and issues of society, and the need to develop and improve the level of university performance in community service.

This study provides a set of recommendations as follows: build and spread the culture of free and voluntary work among graduates, and motivate students in the community and voluntary participation, provide them with entrepreneurial skills, prepare an action plan, Organizing conferences and workshops to spread the concepts and theories of social entrepreneurship, and finding long-term solutions to social problems. 


\section{Limitations and future research}

The model of the study was tested in the branch of Taibah University in the Khyber Governorate in Saudi Arabia. This study has found a strong positive relationship and statistically significant effect of the dimensions of social entrepreneurship in applying the concept of social entrepreneurship. Research in the field of social entrepreneurship is still receiving the attention of many writers and researchers because it is an emerging and fertile field for study.

The researcher recommends conducting more studies in this field dealing with the following issues: the impact of social entrepreneurship on financial performance, the concept of corporate social governance, measuring return on investment in social entrepreneurship.

\section{References}

Abdo, E., Fahmy, A., Greenwald, D. ,and Nelson ,J.,( 2010), “Report on Community Leadership in the Middle East Towards Sustainable Development for the Future Generation - Social and Environmental Sustainability Policy", April 2010, Middle East Youth Initiative, in cooperation between the Wolfensohn Center for Development at the Brookings Institution and the Dubai School of Government, the Arab Thought Foundation for Research and Studies, January 1, 2012, pp. 1-38.

Abu Qarn, S. M., (2015), The Reality of Entrepreneurship in Palestinian Universities in the Gaza Strip - A Comparative Study between the Continuing Education Departments at Al-Azhar and Islamic Universities, Master Thesis, Islamic University of Gaza, Palestine.

Adetu, S., (2014), AIESEC pursues social entrepreneurship for economic development. Spygahna. Retrieved from http://www.spyghana.com/aiesec-pursues-social-entrepreneurship-economic-development/2014,26 September.

Al-Farra, M. I., (2018), degree of practice of Palestinian university students in Gaza governorates for volunteer work and their relationship to leadership skills with a master's thesis, Islamic University of Gaza, Palestine.

Alvord, S.H., Brown, L. D., and Letts, C. W., (2004), Social entrepreneurship and social

Transformation: an exploratory study. The journal of applied behavioural science., 40, no.3, pp. 260-282.

Al-Wafi, A., (2012), "Leadership in Environmental Performance: A Model Nokia Corporation", Al-Muhitin Journal, No. 11, pp. 1-8.

Austin, J., Stevenson, H., and Wei-Skillern, J., (2006), Social and commercial entrepreneurship: Same, different, or both? Entrepreneurship Theory and Practice,30,1, pp.1-22.

Bornstein, D., and Davis, S., (2010), Social entrepreneurship: What everyone needs to know, New York, NY: University Press.

Dacin, P. A., Dacin, M. T., and Matear, M. , (2010), "Social Entrepreneurship: Why We Don't Need a New Theory and How We Move Forward from Here", Academy of Management Perspectives, 24, 3, pp. 37-57.

Dees, J. G., (2007), taking social entrepreneurship, seriously Society, no. 44, pp. $24-31$.

Dees, J. G., (2002), Strategic Tools for Social Entrepreneurs: Enhancing the Performance of Your Enterprising Nonprofit, with co-editors Jed Emerson and Peter Economy San Francisco: Wiley.

Dees, J. G., (2001), The Meaning of "Social Entrepreneurship", The Fuqua School of Business, Duke University.

Dees, J.G., Anderson, B.B., and Wei-Skillern J., (2004), "Scaling Social Impact," Stanford Social Innovation Review, spring 2004,1(4), pp. 24-32.

El Ebrashi, R., (2013), social entrepreneurship theory and sustainable social impact, Social Responsibility Journal, Vol. 9 no. 2, pp. 188-209.

Haider, W. H. M., (2014), "The Youth Initiative and its Relationship with Social Entrepreneurship in Jordanian Civil Society Organizations", unpublished PhD thesis, College of Graduate Studies, University of Jordan, pp. 1-131.

Hartigan P, (2006), It is about people, not profits, Business Strategy Review 17(4), pp. 42-45.

Helm, S. , (2007), Social entrepreneurship: Defining the non-profit behaviour and creating an instrument for measurement, Doctoral dissertation, IN Public Affairs And Administration and Economics, Presented to the Faculty of the University of Missouri-Kansas City, Retrieved from ProQuest Dissertations \& Theses database, (UMI No. 3265545), pp.1-180.

Jiao, H., (2011), A conceptual model for social entrepreneurship directed toward social impact on society, Social Enterprise Journal, Vol. 7 No. 2, pp. 130-149.

Justin D. G., (2012), The Relationship Between Social Entrepreneurship and Organizational Effectiveness, A Dissertation Presented in Partial Fulfilment of the Requirements for the Degree Doctor of Philosophy, Dallas Baptist University, April, pp.1-203.

Kavanagh, C., Murphy, o., and Dwyer, o., (2012), Education is key to fostering entrepreneurial spirit. http://www.irishexaminer.com/business/education-is-key-to-fostering-entrepreneurial-spirit-212911.html. 
Luke, B., and Chu,V.,( 2013)., Social enterprise versus social entrepreneurship: An examination of the 'why and 'how' in pursuing social change, International Small Business Journal, Vol.31,N.7, pp. 764-784.

Mair, J., and Marti, I., (2006), Social entrepreneurship research: a source of explanation, prediction, and delight, Journal of World Business, Vol. 41, pp. 36-44.

Mair, J., and Marti, I., (2004), Social Entrepreneurship Research: A source of Explanation, Predication and Delight, IESE Business School, University of Navarra, Working Paper NO.546, March, pp.1-21.

Mcclave, J.T., Benson, P.G., and Sincich, T.L., (2001), Statistics for Business and Economics, Eight, ed., Prentice Hall, Inc., Canada.

Mort, G. S., Weerawardena, J., and Carnegie, K., (2003), "Social entrepreneurship: Towards conceptualisation", International Journal of Non-profit \& Voluntary Sector Marketing, 8, 1, pp. 76-88.

Offer, A., (2006), the Challenge of Affluence, Oxford.

Robinson, J., (2006), Navigating social and institutional barriers to markets: how social entrepreneurs identify and evaluate opportunities, in Mair, J., Robinson, J. and Hockerts, K. (Eds), Social Entrepreneurship, Macmillan, New York, NY, 2006.

Sagawa, S., and Segal, E., (2000)," Common interest, common good: creating value through business and Social Sector partnership ", California Management Review, 42, 2, pp. 105-122.

Sekaran, U., (2003), Research methods for business: A skill building approach, (4th ed.). India: John Wiley \& Sons Inc.

Social Investment Report of Shell International, (2011), in the Sultanate of Oman, Shell Development Oman LLC, pp. 1-24.

Sullivan, M., G., Weerawardena J., and Carnegie K., (2003) Social entrepreneurship: Towards conceptualization. International Journal of Non-profit and Voluntary Sector Marketing, 8(1), pp.76-88.

Wee-Liang, W., J., and Teck-Meng, T., (2005), “Defining the 'Social' in 'Social Entrepreneurship': Altruism and Entrepreneurship." The International Entrepreneurship and Management Journal. No. 3, pp. 353-365.

Weerawardena, J., and Mort, G.S., (2006), Investigating social entrepreneurship: A multidimensional models, Journal of World Business, Vol. 41, pp. 21-35.

Zeina, A., and Alhabib, T., (2014), "Leadership and Social Responsibility from an Islamic Perspective: A Case Study of Algerian Institutions", The International Hijaz Journal for Islamic and Arabic Stu. 